\title{
Correction: Overshadowed by the amygdala: the bed nucleus of the stria terminalis emerges as key to psychiatric disorders
}

\author{
M. A. Lebow ${ }^{1,2} \cdot$ A. Chen ${ }^{1,2}$ \\ Published online: 7 November 2019 \\ (c) The Author(s) 2019. This article is published with open access
}

Correction to: Molecular Psychiatry (2016) 21:450-463

https://doi.org/10.1038/mp.2016.1

published online 16 February 2016

Following publication of this article, the authors noticed that the legends for Figures 1 and 2 were inadvertently switched. The legend currently associated with Figure 1 actually corresponds to Figure 2, and vice versa. The publishers would like to apologise for this error and any inconvenience it may have caused. This has not been corrected in the PDF or HTML versions of the article.
Open Access This article is licensed under a Creative Commons Attribution-NonCommercial-NoDerivatives 4.0 International License, which permits any non-commercial use, sharing, distribution and reproduction in any medium or format, as long as you give appropriate credit to the original author(s) and the source, and provide a link to the Creative Commons license. You do not have permission under this license to share adapted material derived from this article or parts of it. The images or other third party material in this article are included in the article's Creative Commons license, unless indicated otherwise in a credit line to the material. If material is not included in the article's Creative Commons license and your intended use is not permitted by statutory regulation or exceeds the permitted use, you will need to obtain permission directly from the copyright holder. To view a copy of this license, visit http://creativecommons.org/licenses/by-nc-nd/4.0/.

A. Chen

alon.chen@weizmann.ac.il

alon_chen@psych.mpg.de

1 Department of Neurobiology, Weizmann Institute of Science, Rehovot, Israel

2 Department of Stress Neurobiology and Neurogenetics, MaxPlanck Institute of Psychiatry, Munich, Germany 